Журнал«Герстективита інновації наукиљ

(Серія «Гедагогіка», Серія«Гтихологія», Серія«Медицина»

№(6) 2022

УДК 378:373.2.011.3 -051]004

https://doi.org/10.52058/2786-4952 -2022-1(6)-34-44

Березовська Людмила Іванівна доктор педагогічних наук, доцент, завідувач кафедри теорії i методики дошкільної освіти, Д3 «Південноукраїнський національний педагогічний університет імені К. Д. Ушинського», вул. Старопортофранківська, 26, м. Одеса, 65000, тел.: (048) 732-48-02, https://orcid.org/0000-0002-3032-7261

\title{
ФОРМУВАННЯ ІНФОРМАЦІЙНО-КОМУНІКАЦЙНОӤ КОМПЕТЕНТНОСТІ МАЙБУТНІХ ВИХОВАТЕЛІВ ЗАКЛАДІВ ДОШКІЛЬНОї ОСВІТИ
}

Анотація. У статті здійснено теоретичний аналіз проблеми формування інформаційно-комунікаційної компетентності майбутніх вихователів ЗДО. Обгрунтовано сутність поняття «інформаційно-комунікаційні технології», подано визначення феномену «інформаційно-комунікаційна компетентність майбутнього вихователя ЗДО», яке розуміємо як його здатність використовувати інформаційні і комп'ютерні технології для задоволення власних освітніх потреб та вирішення професійних завдань у роботі з дітьми, підвищення їхньої зацікавленості процесом навчання. Зазначено, що в сучасному освітньому середовищі професійна компетентність майбутнього вихователя ЗДО передбачає володіння сучасними цифровими інструментами. У дослідженні використано загальнотеоретичні (аналіз науково-педагогічної літератури) та емпіричні (аналіз освітніх програм навчальних дисциплін комп'ютерного циклу, спостереження за освітнім процесом у ЗВО та ЗДО (під час проходження студентами педагогічної практики), бесіди із викладачами та студентами, консультації, опитування, експериментальне дослідження щодо виявлення рівнів сформованості інформаційно-комунікаційної компетентності майбутніх вихователів ЗДО. Результати дослідження полягають у сформованості у майбутніх вихователів практичних умінь використовувати сучасні онлайн платформи в освітньому процесі. Задля цього на практичних $\mathrm{i}$ семінарських заняттях студенти створювали мультимедійні презентації із використанням сучасних онлайн платформ, розробляли навчальні ігри та вправи, вікторини для дітей дошкільного віку тощо. На пропедевтичному етапі було проведено 3 викладачами, які були задіяні в експерименті вебінари, консультації, майстер-класи тощо. Доведено, що використання ІКТ у роботі зі студентами підвищує пізнавальну активність, урізноманітнює освітній процес, сприяє розвитку творчості, винахідливості, готовності до використання ІКТ у роботі з дітьми, що $є$ і нормативною і суспільною вимогою.

Ключові слова: інформаційні технології, освітній процес, підготовка, майбутні вихователі, онлайн ресурси. 
Berezovska Liudmyla Ivanivna Doctor of Pedagogical Sciences, Head of the Department of Theory and Methods of Preschool Education at the State institution "South Ukrainian National Pedagogical University named after K. D. Ushynsky", Staroportofrankivska St., 26, Odessa, 65000, tel.: (048) 732-48-02, https://orcid.org/0000-0002-3032-7261

\section{FORMATION OF INFORMATION AND COMMUNICATION COMPETENCE OF FUTURE TEACHERS OF PRESCHOOL EDUCATION INSTITUTIONS}

Abstract. The article provides a theoretical analysis of the problem of formation of information and communication competence of future educators of preschool education. The essence of the concept of "information and communication technologies" is substantiated, the definition of the phenomenon "information and communication competence of the future educator of preschool institutions" is given, which we understand as his ability to use information and computer technologies to, increasing their interest in the learning process. It is noted that in the modern educational environment the professional competence of the future educator of preschool education institutions involves the possession of modern digital tools. In general, theoretical study it is used analyses of pedagogical literature and analysis of educational programs, computer training courses cycle studying of the process of educational institutions of higher education and preschool education (during the Hour of passing students pedagogical study) beside of teachers and students, consultations, surveys, experimental research to identify the levels of information and communication competence of future educators of preschool education. The results of the study are the formation of future educators' practical skills to use modern online platforms in the educational process. To this end, in practical and seminar classes, students created multimedia presentations using modern online platforms, developed educational games and exercises, quizzes for preschool children and more. At the propaedeutic stage, webinars, consultations, master classes, etc. were held with teachers who were involved in the experiment. It is proved that the use of ICT in working with students increases cognitive activity, diversifies the educational process, promotes creativity, ingenuity, readiness to use ICT in working with children, which is a normative and social requirement.

Keywords: information technologyand, educational process, training, future educators, online resources.

Постановка проблеми. Упродовж останніх років у системі освіти України відбуваються кардинальні зміни, спричинені діджиталізацією суспільства, активним використанням в освітньому процесі сучасних цифрових технологій, що вимагає якісно нового рівня підготовки фахівців творчо мислячих, креативних, рішучих, які з легкістю адаптуються до 
суспільних викликів, конкурентноздатні на міжнародному та світовому рівнях.

Ефективність підготовки майбутніх вихователів закладів дошкільної освіти (далі - ЗДО) залежить від рівня набутих знань, сформованих практичних умінь та навичок, необхідних для успішного здійснення професійної діяльності. ЗДО потребують фахівців-вихователів нової формації, які виявляють творчі вміння, сприяють розкриттю потенційних можливостей дитини, створюють сприятливе освітньо-розвивальне середовище, впроваджують нові проєкти, ідеї, інноваційні технології. Інноваційні процеси в системі освіти України потребують внесення коректив у наявні методики навчання та виховання підростаючої особистості, впровадження сучасних інноваційних технологій в організацію освітнього процесу, які б сприяли розвитку творчості дітей, формуванню у них пізнавальної активності, допитливості, ініціативності, самостійності у прийнятті рішень.

Реформування нової української школи (далі - НУШ) яке розпочалося ще у 2018 році, вимагає відповідних змін у дошкільній ланці освіти, зокрема це стосується і формування у випускників ЗДО дошкільної зрілості у зв'язку 3 переходом у нову соціально-освітню установу - школу. У зв’язку з цим у 2021 р. було оновлено Державний стандарт дошкільної освіти (Базовий компонент дошкільної освіти, 2021), розроблено методичні рекомендації до роботи 3 документом, програму підвищення кваліфікації педагогічних працівників щодо впровадження оновленого Базового компонента дошкільної освіти.

Отже, важливо, щоб майбутні вихователі у процесі професійної підготовки у закладах вищої освіти (далі - ЗВО) оволоділи грунтовними теоретичними знаннями та вміннями, які дозволять їм у майбутньому вирішувати складні професійні завдання, покладені державою щодо виховання, навчання та соціалізації молодого покоління.

Аналіз останніх досліджень і публікацій. Особливості впровадження інформаційно-комунікаційних технологій в освітній процес ЗВО висвітлюється в наукових доробках як українських (В. Биков, І. Богданова, В. Дем’яненко, С. Сисоєва, О. Співаковський, I. Тимофєєва, Т. Шроль та ін.), так і зарубіжних (П. Вастіа (Р. Wastiau), Р. Бламір (R. Blamire), К. Кipні (C. Kearney), В. Квітр (V. Quittre), Е. Ван де Гаер (Е. Van de Gaer), Хр. Монсер (Chr. Monseur) учених. Окремі аспекти готовності майбутніх педагогів до формування цифрової компетентності дітей дошкільного та молодшого шкільного віку розкрито в дослідженнях А. Богуш, С. Дяченко, І. Мардарової, Л. Петухової, Н. Сороки, I. Тимофєєвої, Т. Чекан та інших науковців. Проте, як засвідчує практика, інформаційно-комунікаційні технології (далі - IKT) не знайшли ще належного впровадження у 3ВО, зокрема відсутнє в достатній мірі оновлене методичне та технічне забезпечення. Низький рівень підготовки викладачів та їхнє розуміння необхідності застосування ІКТ в освітньому процесі створює перешкоди для активного їх впровадження в освітній процес ЗВО.

Метою дослідження $\epsilon$ формування інформаційно-комунікаційної компетентності майбутніх вихователів закладів дошкільної освіти. 


\section{Виклад основного матеріалу. Методологія та методи}

Для вирішення поставлених у дослідженні завдань було використано комплекс загальнотеоретичних (аналіз та узагальнення науково-педагогічної літератури, моделювання освітнього процесу); емпіричних (аналіз освітніх програм навчальних дисциплін пов'язаних з ІКТ, спостереження за освітнім процесом у ЗВО та ЗДО під час проходження студентами педагогічної практики, бесіди із викладачами та студентами, консультації, опитування, експериментальне дослідження щодо виявлення рівнів сформованості інформаційно-комунікаційної компетентності (далі - IКК) майбутніх вихователів ЗДО).

\section{Результати та дискусії}

Швидкий розвиток IКТ вимагає широкого їх впровадження в усіх галузях виробництва, зокрема в науці та освіті. Інформатизація в освіті - це створення i використання інформаційних технологій для досягнення оптимальних результатів діяльності, з меншими затратами ресурсів (часових, матеріальних, фінансових) [1, с. 6]. Завдяки зменшенню часових затрат і збереженню розумової працездатності ІКТ в освітньому процесі створюють оптимальні умови для розвитку творчих здібностей студентів, добору способів виконання завдань різних рівнів складності, індивідуалізації та диференціації навчання, оцінювання результатів діяльності здобувачів освітнього процесу [6, с. 9].

Важливість упровадження в освітній процес ІКТ підтверджується і нормативно-правовими документами, зокрема Законом України «Про вищу освіту» (2014 р.), Законом України «Про Національну програму інформатизації» (проєкт від $2021 \mathrm{p}$ ), Концепцією розвитку цифрових компетентностей та затвердження плану заходів із іï реалізації (2021р.), Положенням про електронні освітні ресурси (2019), а також створенням Міністерства та Комітету цифрової трансформації України (2019 р). Так, у Концепції розвитку цифрових компетентностей (Концепція розвитку цифрових компетентностей, 2021) феномен «цифрова компетентність» визначається як комбінування знань, умінь, навичок, способів мислення, поглядів, особистісних якостей у сфері інформаційно-комунікаційних та цифрових технологій, що сприяє успішній соціалізації особистості, ефективній професійно-освітній діяльності із застосуванням IKT. На необхідності впровадження ІКТ в освітній процес наголошується і в БКДО [7]. У документі зазначено, що дитина дошкільного віку має мати уявлення про ІКТ як сучасні технічні засоби навчання, що розширюють ii інформаційну обізнаність та сприяють успішній соціалізації у сучасному інформатизованому суспільстві. Поняття «цифрова компетентність» розуміється, як здатність дитини використовувати ІКТ та цифрові ресурси для задоволення власних та освітніх потреб, ігрових завдань на основі набутих елементарних знань.

Крім того, задля забезпечення наступності між дошкільною та початковою ланками освіти вихователям ЗДО необхідно враховувати вимоги Концепції Нової української школи та формувати у вихованців ключові 
компетентності, серед яких провідними є: IKК, яка передбачає опанування цифрової грамотності, вміле використання IКТ у навчанні та інших життєвих ситуаціях, навчання упродовж життя [10].

Проте, не зважаючи на чималий перелік нормативно-правових документів у галузі ІКТ, створенні спеціальних установ та відомств, проблема впровадження IКТ так і не знайшла належної реалізації в освітньому процесі 3ВО, зокрема на гуманітарних спеціальностях, про що засвідчують результати проведеного експериментального дослідження щодо 3’ясування рівнів сформованості ІКК у майбутніх вихователів ЗДО.

У науковому обігу наявні різні поняття, дотичні дефініції «інформаційнокомунікаційні технології», зокрема: «комп'ютерні технології навчання», «інформаційні технології», «нові інформаційні технології», «цифрові технології навчання».

Так, у великому тлумачному словнику української мови [2, с. 512] подано термін «інформаційна технологія», який тлумачиться як: сукупність інформаційних процесів із використанням засобів обчислювальної техніки, що забезпечують швидкий пошук інформації, доступ до джерел інформації. У спеціалізованому словнику з інформаційно-комунікаційних технологій [3, с. 53]. подано термін «ІКТ в освіті», який розглядається як «сукупність методів, прийомів, виробничих процесів і програмно-апаратних засобів, інтегрованих для розроблення інформаційно-цифрових освітніх систем, електронних освітніх ресурсів та побудови комунікаційних мереж, а також технології розв’язування задач у галузі освіти з використанням таких систем, ресурсів i мереж».

Вчені (О. Гуляєва, Ю. Іващенко, Л. Петречук, О. Соболенко, В. Толстой, Г. Швачич) під інформаційно-комунікаційними технологіями розуміють сукупність методів, виробничих процесів, програмно-технічних засобів, інтегрованих для збирання, оброблення, зберігання, розповсюдження, демонстрації та використання даних в інтересах їх користувачів [13].

Зарубіжні дослідники (Сімін Гавіфекр (Simin Ghavifekr) та Ван Атіра Ван Росд (Wan Athirah Wan Rosd) уважають, що IKT здатні забезпечити динамічне та активне середовище для викладання та навчання і мають бути включені у щоденний освітній процес у роботі із вихованцями. Педагогів учені розглядають як ключових гравців у використанні ІКТ в освітньому процесі [16].

Використання IКT у вищій освіті, на думку Ю. Триуса, «сприяє розкриттю, збереженню і розвитку індивідуальних інтересів; формуванню пізнавальних інтересів, прагненню до самовдосконалення та самореалізації студентів; забезпеченню комплексності вивчення явищ дійсності, нерозривності взаємозв'язку між природознавством, технікою, гуманітарними науками і мистецтвом; постійному динамічному оновленню змісту, засобів, форм і методів навчання і виховання» [11, с. 22].

Таким чином, IКТ є потужним інструментом для реформування системи освіти, сприяють накопиченню нових знань шляхом необмеженого доступу до 
вибору та інтерпретації інформації, критичного іiі оцінювання, інтегрують теоретичне навчання із формуванням практичних умінь вирішувати професійно спрямовані завдання, підвищують якість підготовки майбутніх педагогів, орієнтують здобувачів освітнього процесу на самостійне навчання, забезпечують творчо-розвивальне середовище для навчання [14].

I. Мардарова, досліджуючи підготовку майбутніх вихователів до використання комп'ютерних технологій в організації пізнавальної діяльності старших дошкільників визначає показники їхньої готовності, зокрема: обізнаність вихователів із використанням комп'ютерних технологій у роботі 3 дітьми; володіння формами і методами організації пізнавальної діяльності дітей засобами комп'ютерних технологій; оцінювання ефективності розроблених дидактичних матеріалів засобами IКТ; бажання та вміння вихователів застосувати комп'ютерні технології у майбутній професійній діяльності [4, с. 169].

Застосування комп'ютерних технологій у професійній діяльності вихователя ЗДО було предметом дослідження О. Чекан. Професійну компетентність майбутніх вихователів ЗДО засобами комп'ютерних технологій дослідниця визначає як інтегроване, особистісно-ціннісне, полікомпонентне утворення на основі сформованих фахових знань, умінь і навичок засобами комп'ютерних технологій [12, с. 23].

I. Тимофєєва під ІКК майбутнього вихователя ЗДО розуміє інтегративну, динамічну характеристику фахівця, що презентує вмотивованість і здатність орієнтуватися в інформаційному просторі дошкільної галузі освіти, отримувати та систематизувати інформацію щодо науково-методичного супроводу освітнього процесу ЗДО, оперувати нею у роботі 3 дітьми дошкільного віку $[9$, с. 3].

У дослідженні під ІКК майбутніх вихователів ЗДО розуміємо їх здатність використовувати інформаційні і комп'ютерні технології для задоволення власних освітніх потреб та вирішення професійних завдань у роботі з дітьми, підвищення їхньої зацікавленості процесом навчання.

Таким чином, інформатизація освіти $\epsilon$ важливим етапом розвитку сучасного суспільства та підготовки компетентних фахівців, здатних ефективно впроваджувати новітні методи та IКТ у майбутній професійній діяльності, задовольняти індивідуальні потреби, самовдосконалюватися та саморозвиватися у професії. Задля цього у ЗВО необхідно створити умови, які сприятимуть ефективному формуванню ІКК майбутніх вихователів ЗДО, активно використовувати інноваційні методи та технології навчання, ігрові та мобільно зорієнтовані цифрові ресурси для навчання, проєктні методики зі створенням мультимедійних презентацій, метод проблемного навчання, виконання практичних завдань студентами із використанням цифрових інструментів (розроблення ігор, вправ та завдань для дітей дошкільного віку). Зауважимо, що сучасні тенденції розвитку дошкільної освіти передбачають осучаснення та збагачення іiі змісту інноваційними освітніми та 
інтерактивними технологіями у роботі з дітьми, що здатні забезпечити їхню цифрову грамотність. Переконані, що активне використання цифрових технологій в освітньому процесі ЗВО забезпечить опанування студентами нових цифрових ресурсів, що дозволить модернізувати освітній процес, підвищити ефективність навчання, створити умови для активної взаємодії зі здобувачами вищої освіти; розвинути їхні інтелектуальні, творчі здібності, пізнавальну активність та мотиваційну спрямованість навчання; сформувати практичні вміння у процесі виконання професійно зорієнтованих завдань; забезпечити активне входження в цифровий інформаційний простір.

Для виявлення рівнів сформованості ІКК студентами спеціальності 012 «Дошкільна освіта» ДЗ «Південноукраїнський національний педагогічний університет імені К. Д. Ушинського» було проведено опитування, у якому взяли участь 67 студентів 2-х - 4-х курсів. Результати опитування засвідчили здебільшого задовільний (38 \%) та низький (23\%) рівні сформованості ІКК майбутніх вихователів ЗДО. Високому рівню сформованості ІКК відповідали $16 \%$ студентів, достатньому $-23 \%$.

У ході експериментального дослідження було проаналізовано навчальні плани та робочі програми дисциплін пов'язаних 3 IKT. Аналіз їх змісту засвідчив, що більшість із них зорієнтовані на формування у студентів ІКК на рівні користувача, а не практико-зорієнтованості на майбутню професію вихователя. Жодна 3 програм не містила завдань, які передбачали б ознайомлення студентів із цифровими ресурсами, які доцільно використовувати як на заняттях, так i в повсякденній роботі 3 дітьми дошкільного віку, створювати ігрові завдання та вправи. Опитування викладачів факультету дошкільної педагогіки та психології Д3 «Південноукраїнський національний педагогічний університет імені К. Д. Ушинського» засвідчили, що лише $19 \%$ викладачів використовують у роботі зі студентами IКТ, $32 \%$ - використовують частково, $38 \%$ - виносять на самостійне опрацювання, $11 \%$ викладачів - не використовують узагалі. Завдання, які пропонували викладачі студентам, полягали у створенні мультимедійних презентацій, побудові схем, таблиць, графіків для оформлення наукових досліджень, презентації матеріалів занять. Жоден 3 опитаних педагогів не вказав на використання онлайн сервісів для створення інтерактивних вправ, ігрових завдань, проведення опитування та оцінювання студентів засобами цифрових інструментів тощо.

Задля підвищення рівнів сформованості ІКК у процесі вивчення дисципліни «Методика формування елементарних математичних уявлень у дітей дошкільного віку» в роботі зі студентами було впроваджено ІКТ. Так, до кожної лекції розроблено мультимедійну презентацію із використанням онлайн сервісів Canva, Prezi, Google Presentations, Piktochart, Projeqt та ін. Це надало можливість продемонструвати студентам можливості онлайн сервісів для створення мультимедійних презентацій, наповнюючи їх різноманітними матеріалами, фото та відео картинками, готовими шаблонами, інфографікою, 
анімацією, слайдами тощо, що значно полегшило роботу педагога у процесі висвітлення матеріалу.

На практичних заняттях студенти створювали інтерактивні ігри для дітей, розробляли вікторини, квести засобами онлайн-платформ Kahoot, LearningApps.org, Matific за темами, передбаченими освітньою програмою навчальної дисципліни. Створені завдання здобувачі освітнього процесу активно впроваджували на заняттях 3 дітьми під час проходження педагогічної практики.

На семінарських заняттях практикували зі студентами проведення вебінарів, як-от: «Сучасні погляди на формування логіко-математичної компетентності дітей дошкільного віку», «Проєктна діяльність на заняттях із формування елементарних математичних уявлень у дітей», «Математичні задачі-жарти, ребуси, головоломки, лабіринти у формуванні логікоматематичної та дослідницької компетентності дітей старшого дошкільного віку». Студенти працювали в групах. Кожна група позиціонувала тему вебінару та створювала презентаційні матеріали на запропонованих онлайнплатформах використовуючи слайди із посиланнями на YouTube-відео, аудіо; проводили опитування та тестування, демонструючи в діаграмах результати навчання; створювали питальники в Google Формах; проводили відеоконференції з тем, що виносилися на самостійне опрацювання.

Самостійна робота студентів передбачала створення інформаційного сайту для батьків «Розвиваємо логіко-математичну компетентність дітей дошкільного віку» та розроблення конспектів занять із використанням IКТ.

Із викладачами професійно спрямованих навчальних дисциплін було проведено вебінар 3 теми «Інформаційно-комунікаційні технології в освітньому процесі 3ВО». На вебінарі представлено сучасні цифрові ресурси та розглянуто особливості їх використання в освітньому процесі ЗВО, розкрито практичний аспект та можливості їх використання в роботі зі студентами.

На підсумковому етапі експериментального дослідження задля з'ясування рівнів сформованості ІКК було проведено чергове онлайн опитування студентів та викладачів. Отримані результати засвідчили позитивні зміни. Так, високому рівню сформованості ІКК після експериментального етапу дослідження відповідало 36,7\% студентів (було $16 \%$ ), достатній рівень засвідчили 29,5 \% студентів (було $23 \%$ ), задовільний рівень сформованості IКК продемонстрували $24,6 \%$ опитаних (було $38 \%$ ), на низькому рівні залишилося 9,3\% студентів (було $23 \%$ ).

Опитування викладачів також засвідчило позитивні зміни. $67,3 \%$ професорсько-викладацького складу факультету на запитання анкети «Чи будете використовувати IКТ в роботі зі студентами» дали ствердну відповідь «Так». Респонденти зазначили, що вебінар та консультації, в яких вони брали участь упродовж семестру, сприяли вдосконаленню їхньої ІКК, вмінню створювати власні мультимедійні розробки, користуючись сучасними 
освітніми онлайн платформами, розробляти ілюстровані методичні та наочні матеріали, питальники за допомогою цифрових онлайн ресурсів, необхідних для успішного здійснення професійної діяльності в умовах інформатизації освітнього процесу.

Висновки. В умовах цифрової інформатизації суспільства виникає необхідність опанування майбутніми вихователями ЗДО інформаційнокомунікаційних технологій навчання. Використання IКТ в освітньому процесі 3ВО урізноманітнює роботу з навчальної інформації, забезпечує включення студента в активно-пізнавальну та пошуково-дослідницьку діяльність, сприяє кращому засвоєнню матеріалу завдяки унаочненню, формує практичні вміння щодо створення онлайн завдань, розвиває творчість, ініціативність наполегливість, сприяє самонавчанню.

Водночас вагомою проблемою впровадження IКТ в освітній процес здебільшого $\epsilon$ низький рівень ІКК викладачів ЗВО, про що засвідчили результати опитування, використання в роботі традиційних форм та методів, низький рівень мотивації. Причиною цього є відчуття напруженості та страху від інноваційних процесів у системі освіти. Задля підвищення рівня ІКК необхідно мотивувати викладачів до проходження курсів підвищення кваліфікації із цифрової грамотності, організовувати вебінари, майстер-класи, здійснювати самооцінку професійної діяльності, займатися самоосвітою. Організація освітнього процесу в сучасних умовах повинна забезпечити активне використання IКТ у роботі зі студентами, майбутніми вихователями ЗДО, адже від сформованості IКК залежатиме використання цифрових ресурсів у роботі з дітьми дошкільного віку.

Перспективи подальших досліджень убачаємо у розкритті особливостей використання інтерактивних технологій у процесі формування логіко-математичного розвитку дітей дошкільного віку.

\section{Лimepamypa:}

1. Биков В. Ю. Засоби інформаційно-комунікаційних технологій єдиного інформаційного простору системи освіти України: монографія. Київ : Педагогічна думка, 2010. 160 с.

2. Великий тлумачний словник української мови / уклад. і голов. ред. В. Бусел. Київ : Ірпінь, ВТФ «Перуһ», 2005. 1728 с.

3. Інформаційно-комунікаційні технології в освіті : словник. Київ: ЦП Компринт, 2019. $134 \mathrm{c}$.

4. Мардарова I. К. Підготовка майбутніх вихователів до використання комп’ютерних технологій в організації пізнавальної діяльності старших дошкільників : дис. ... канд. пед. наук : 13.00.08. Одеса, 2012. 239 с.

5. Міністерство освіти і науки України. URL: https://mon.gov.ua/ua (Дата звернення 29.09.2021).

6. Петухова Л. Є. Теоретико-методичні засади формування інформатичних компетентностей майбутніх учителів початкових класів : автореф. дис. ... доктора пед наук: 13.00.04. Одеса, 2009. 50 c.

7. Про затвердження Базового компонента дошкільної освіти від 12.01. 2021 № 33 c. 26 URL: https://mon.gov.ua/storage/app/media/rizne/2021/12.01/Pro_novu_redaktsiyu\%2 0Bazovoho\%20komponenta\%20doshkilnoyi\%20osvity.pdf (Дата звернення: 20.09.2021). 
8. Про схвалення Концепції розвитку цифрових компетентностей та затвердження плану заходів з іiї реалізації. Схваленої Кабінету Міністрів України від 3 березня 2021 р. № 167-p. URL: https://zakon.rada.gov.ua/laws/show/167-2021-\%D1\%80\#Text (Дата звернення: 27.09.2021).

9. Тимофєєва I. Б. Формування інформаційно-комунікаційної компетентності майбутніх вихователів дошкільних навчальних закладів : автореф. дис. ... канд. пед. наук : 13.00.08. Київ, 2017. 23 с.

10. Типова освітня програма, розроблена під керівництвом О. Савченко Наказ Міністерства освіти i науки України від 08.10.2019 року № 1272 URL: https://mon.gov.ua/ storage/app/media/zagalna\%20serednya/programy-1-4-klas/2019/11/1-2-dodatki.pdf (Дата звернення: 27.09.2021).

11. Триус Ю. В. Комп'ютерно-орієнтовані методичні системи навчання математичних дисциплін у вищих навчальних закладах : автореф. ...д-ра пед. наук : 13.00.0.2. Київ, 2005. 48 с.

12. Чекан О. І. Застосування комп’ютерних технологій у професійній діяльності вихователя дошкільного навчального закладу : навч. посіб. Київ : Видавничий Дім «Слово», 2015. 184 с.

13. Швачич Г. Г, Толстой В. В., Петречук Л. М., І Іващенко Ю. С., Гуляєва О. А., Соболенко О. В. Сучасні інформаційно-комунікаційні технології : навч. посіб. Дніпро: НМетАУ, 2017. $230 \mathrm{c}$.

14. Jo Shan Fu (2013) ICT in Education: A Critical Literature Review and Its Implications. International Journal of Education and Development using Information and Communication Technology (IJEDICT), Vol. 9, Issue 1, pp. 112-125. [in English].

15. P. Wastiau, R. Blamire, C. Kearney, V. Quittre, E. Van de Gaer, Chr. Monseur (2013) "The Use of ICT in Education: a survey of schools in Europe", European Journal of Education: Research, Development and Policy. Volume 48, Issue 1. Special Issue: ICT and Education: taking stock of progress and looking at the future, pp. 11-27. [in English].

16. Simin Ghavifekr, Wan Athirah Wan Rosdy (2015). Teaching and Learning with Technology: Effectiveness of ICT Integration in Schools. International Journal of Research in Education and Science. Volume 1, Issue 2, Summer. Retrieved from: https://files.eric.ed.gov/fulltext/EJ1105224.pdf [in English].

\section{References:}

1. Bykov, V. Yu. (2010). Zacoby infopmatsiino-komynikatsiinyx texnolohii yedynoho infopmatsiinoho ppoctopy cyctemy ocvity Ukpaïny [Means of information and communication technologies of the unified information process of the education system of Ukraine] : monohpafiia. Kyiv: Pedahohichna dymka. [in Ukrainian].

2. Belykyi tlymachnyi clovnyk ykpaïnckoï movy (2005). [Great explanatory dictionary of the Ukrainian language] / yklad. i holov. ped. B. Bycel. Kyiv. [in Ukrainian].

3. Informatsiino-komunikatsiini tekhnolohii v osviti (2019) [Information and communication technologies in education] : slovnyk. Kyiv. [in Ukrainian].

4. Mardarova, I. K. (2012). Pidhotovka maibutnikh vykhovateliv do vykorystannia kompiuternykh tekhnolohii $\mathrm{V}$ orhanizatsii piznavalnoi diialnosti starshykh doshkilnykiv [Preparation of future educators for the use of computer technology in the organization of cognitive activity of senior preschoolers] : Extended abstract of candidate's thesis. Odesa. [in Ukrainian].

5. Ministerstvo osvity i nauky Ukrainy [Ministry of Education and Science of Ukraine] Retrieved from: https://mon.gov.ua/ua [in Ukrainian].

6. Petukhova, L. Ye. (2009). Teoretyko-metodychni zasady formuvannia informatychnykh kompetentnostei maibutnikh uchyteliv pochatkovykh klasiv [Theoretical and methodological principles of formation of computer competencies of future primary school teachers]. Extended abstract of Doctor's thesis. Odesa. [in Ukrainian]. 
7. Pro zatverdzhennia Bazovoho komponenta doshkilnoi osvity (2021) [About the statement of the Basic component of preschool education]. Retrieved from: https://mon.gov.ua/storage/ app/media/rizne/2021/12.01/Pro_novu_redaktsiyu\%20Bazovoho\%20komponenta\%20doshkilnoyi $\% 20$ osvity.pdf [in Ukrainian].

8. Pro skhvalennia Kontseptsii rozvytku tsyfrovykh kompetentnostei ta zatverdzhennia planu zakhodiv z yii realizatsii, (2021) [On approval of the Concept of development of digital competencies and approval of the action plan for its implementation]. Retrieved from: https://zakon.rada.gov.ua/laws/show/167-2021-\%D1\%80\#Text [in Ukrainian].

9. Tymofieieva, I. B. (2017). Formuvannia informatsiino-komunikatsiinoi kompetentnosti maibutnikh vykhovateliv doshkilnykh navchalnykh zakladiv [Formation of information and communication competence of future educators of preschool educational institutions] : Extended abstract of candidate's thesis. Kyiv [in Ukrainian].

10. Typova osvitnia prohrama, rozroblena pid kerivnytstvom O. Savchenko [A typical educational program developed under the guidance of O. Savchenko]. Retrieved from: https://mon.gov.ua/ storage/app/media/zagalna\%20serednya/programy-1-4-klas/2019/11/1-2-dodatki.pdf [in Ukrainian].

11. Tryus, Yu. V. (2005). Kompiuterno-oriientovani metodychni systemy navchannia matematychnykh dystsyplin u vyshchykh navchalnykh zakladakh [Computer-oriented methodical systems of teaching mathematical disciplines in higher educational institutions]. Extended abstract of Doctor's thesis. Kyiv. [in Ukrainian].

12. Chekan, O. I. (2015). Zastosuvannia kompiuternykh tekhnolohii u profesiinii diialnosti vykhovatelia doshkilnoho navchalnoho zakladu [The use of computer technology in the professional activities of a preschool teacher] : navch. posib. Kyiv. [in Ukrainian].

13. Shvachych H. H, Tolstoi V. V., Petrechuk L. M., Ivashchenko Yu. S., Huliaieva O. A., Sobolenko O. V. (2017). Suchasni informatsiino-komunikatsiini tekhnolohii [Modern information and communication technologies]: Navchalnyi posibnyk. Dnipro. [in Ukrainian].

14. Jo Shan Fu (2013) ICT in Education: A Critical Literature Review and Its Implications. International Journal of Education and Development using Information and Communication Technology (IJEDICT), Vol. 9, Issue 1, pp. 112-125. [in English].

15. P. Wastiau, R. Blamire, C. Kearney, V. Quittre, E. Van de Gaer, Chr. Monseur (2013) "The Use of ICT in Education: a survey of schools in Europe", European Journal of Education: Research, Development and Policy. Volume 48, Issue 1. Special Issue: ICT and Education: taking stock of progress and looking at the future, pp. 11-27. [in English].

16. Simin Ghavifekr, Wan Athirah Wan Rosdy (2015). Teaching and Learning with Technology: Effectiveness of ICT Integration in Schools. International Journal of Research in Education and Science. Volume 1, Issue 2, Summer. Retrieved from: https://files.eric.ed.gov/fulltext/EJ1105224.pdf [in English]. 